\title{
Avaliação do espaço público urbano: Passeio das Virtudes, Porto, Portugal
}

\author{
Evaluación del espacio público urbano: Paseo de las Virtudes, \\ Porto, Portugal
}

\author{
Evaluation of the urban public space: Passeio das Virtudes, \\ Porto, Portugal
}

Cauê Martins Rios

cauerios@hotmail.com

Universidade do Porto, Portugal

Luiza Rabaça Loureiro Bruno Bispo

luizarabaca@hotmail.com

Universidade do Porto, Portugal

Fernando Manuel Brandão Alves alves@fe.up.pt

Universidade do Porto, Portugal

Carolina Aquino Amador

carolina.arq17@gmail.com

Universidade do Porto, Portugal

Luis Guilherme Aita Pippi guiamy@hotmail.com

Universidade Federal de Santa Maria, UFSM, Santa Maria, RS

Ana Catarina Pinto Barbosa

catarinab04@gmail.com

Universidade do Porto, Portugal

Resumo: através desse trabalho se elaborou um diagnóstico do espaço público do Passeio das Virtudes, na cidade do Porto, um local de grande importância e aglomeração de pessoas, negligenciado pelo munícipe. Para tal, utilizou-se revisão bibliográfica referente à relação das cidades com seus espaços públicos e suas transformações até a contemporaneidade; e análise qualitativa estruturada em quatro dimensões: física, funcional, social e histórico-cultural. Sendo assim, conhecendo a região e as necessidades do público usuário do espaço, foi possível evidenciar os pontos positivos do ambiente do Passeio das Virtudes. A busca de informações e diagnósticos que proporcionem à 
cidade um ambiente urbano ainda mais vivo, de atração ao público, que garante bemestar, segurança, conforto e acessibilidade aos usuários, vai ao encontro das políticas de dinamização e transformação do lugar num polo de cultura e lazer.

Palavras-chave: coletivo; paisagem; interação social; qualidade; diagnóstico.

Resumen: El objetivo es desarrollar un diagnóstico del espacio público del Passeio das Virtudes en Porto, Portugal. Siendo un lugar de gran importancia y aglomeración de personas que es usualmente obviado por el ciudadano. Para ello, se utilizó como herramienta la revisión bibliográfica referente a la relación de las ciudades con sus espacios públicos y las transformaciones de estos hasta la actualidad. Sumado a ello, se utilizó la metodología de análisis cualitativo, estructurada en cuatro dimensiones: física, funcional, social e histórico-cultural. De esta manera, conociendo la región y las necesidades del público que utiliza el espacio, se pudieron destacar los aspectos positivos del entorno del Passeio das Virtudes. La búsqueda de información y diagnósticos que doten a la ciudad de un entorno urbano aún más vivo, de atracción para el público, que garantice el bienestar, la seguridad, el confort y la accesibilidad a los usuarios, cumple con las políticas de dinamización y transformación del lugar en un polo de cultura y ocio.

Palabras clave: colectivo; paisaje; interacción social; calidad; diagnóstico.

\begin{abstract}
This paper aims to elaborate a diagnosis of the public space of Passeio das Virtudes, in Porto, Portugal. As a place of great importance, and agglomeration of people, it is neglected by the citizen. It was performed first a bibliographical revision, referring to the relation of the cities with their public spaces and the transformations of the same ones until nowadays. In addition, it was made a qualitative analysis structured in four dimensions: physical, functional, social, and historical-cultural. Thus, knowing the region and the needs of the uses of the space it was possible to highlight the positive aspects of Passeio das Virtudes environment. By seeking information and diagnoses that provide the city with an even more lively urban environment, of attraction to the public, which ensures well-being, safety, comfort, and accessibility to users, we are thus meeting the policies of revitalisation and transformation of the place into a pole of culture and leisure.
\end{abstract}

Keywords: collective; landscape; social interaction; quality; diagnosis.

\title{
INTRODUÇÃO
}

A partir de 2001, ao tornar-se a Capital Europeia da Cultura, a cidade do Porto recebeu diversos investimentos de programas a nível nacional e europeu, como por exemplo Porto 2001 e Polis, os quais modificaram e requalificaram diversos sítios da cidade, colocando-a em voga para o desenvolvimento dos seus espaços intraurbanos e consequentemente fortalecendo a atração para o turismo.

Muitas áreas da cidade, as quais não estão nos holofotes das zonas turísticas a serem requalificadas, foram esquecidas ou não colocadas em pauta, apesar de necessitarem de maior enfoque. Como por exemplo, o Passeio das Virtudes, o muito importante para a cidade do Porto, seja por fatores históricos seja por sua posição privilegiada em relação a paisagem do Douro. Este trabalho analisou in loco este espaço público intraurbano quanto às suas características, pontos positivos e negativos, para assim compreender o local e construir um diagnóstico para futuras intervenções. Além disso, como aporte teórico 
pré-análise in loco, propõe-se um breve debate sobre a importância dos espaços públicos nas cidades, qual seu papel como elemento integrador e estimulador da vida urbana, bem como as discussões referentes a posição destes locais na contemporaneidade.

Destaca-se, também, importância de se estudar e propor um olhar aos espaços públicos enquanto local de expressão política das forças sociais. Castro $(2013$, online.) reforça por outro lado que, quando no plural, espaços públicos remetem aos lugares urbanos que "em conjunto com infraestruturas e equipamentos coletivos, dão suporte à vida em comum: ruas, avenidas, praças, parques". Além disso, possuem significados simbólicos e palco de expressões ideológicas, festas, comemorações, manifestações políticas, entre outras.

Essas inter-relações promovidas nos espaços de uso coletivo, podem ser complexos objetos de estudo e variam em cada país e cultura. Quando se analisa estes aspectos discutese o espaço público como um dos vetores da condição social e culturalmente pública das cidades (CASTRO, 2002; CASTRO, 2013).

Dada essa importância, para o entendimento mais alargado do espaço em questão, fez-se uma a avaliação do espaço público intraurbano através de uma análise de acordo com as dimensões físicas, funcionais, sociais e histórico culturais, com a intenção de conhecer todas as potencialidades da área e seus pontos com necessidade de melhorias. Com a sequência dos resultados obtidos a partir da análise e da investigação sobre a zona, foi possível levantar hipóteses de interpretação acerca do espaço público e da sua qualidade, dando-se, assim, um diagnóstico para o local.

A partir de todo o estudo realizado, foi possível chegar ao diagnóstico e entendimento de potencialidades e fragilidades do espaço, que é o principal objetivo do presente trabalho. Para por fim, traçar planos para uma maior potencialização de seus pontos positivos e reduzir os negativos, de forma a dar uma melhor qualificação para o espaço público estudado.

\section{ESPAÇOS PÚBLICOS: OS LOCAIS VITAIS DOS CENTROS URBANOS}

Com a democracia admitiu-se que poderia haver estranhamentos dos grupos sociais interagindo no mesmo espaço. Ocorre que o pluralismo de pessoas raramente se verifica nestes espaços, ideia que apagou a própria essência do espaço público. Esta consequência se apoia em três segmentos: "a promoção do espaço individual/privado, a necessidade dos espaços coletivos e a desvalorização social do usufruto do espaço público" (GONÇALVES, 2004, p. 68).

Segundo Gehl e Gemzøe (2000), entre as décadas de 1930 e 1980, os espaços públicos foram negligenciados pois os modernistas, segundo os autores, deram as costas para a cidade e seus espaços urbanos. Outro fator foi o aumento dos transportes motorizados, em que se deu mais evidência para o tráfego e para as rodovias.

Essa visão começou a mudar na década de 70 quando iniciaram os debates envolvendo as cidades sobre questões da qualidade de vida, da poluição, da mobilidade, sendo os carros vistos como invasores das ruas e praças urbanas. No século XX, a arquitetura do espaço público viu-se em constante mudança, colocando os conceitos citados anteriormente em 
pauta. Então, inúmeros espaços públicos novos foram criados, e a atenção para as cidades e para com a interação entre o cotidiano das pessoas e estes locais despertaram diferentes debates (GEHL; GEMZØE, 2000).

Rolnik (1998) também discorre sobre o tema dos espaços públicos na atualidade resumirem-se em locais de circulação de veículos. Enquanto as áreas de lazer e permanência estão sendo levadas para espaços privados, como shopping centers e centros comerciais fechados, atendendo a população de uma faixa de renda restrita, excluindo desses espaços a classe de baixa renda.

Gehl e Gemzoe (2000) citam que, através dos usos correntes do espaço público, existem quatro tipos de cidade:

A cidade tradicional - onde lugares de encontro, de comércio e de circulação continuam a coexistir em equilíbrio.

A cidade invadida - onde usos individuais, geralmente o tráfego de carros, usurpa território à custa de outros usos do espaço urbano.

A cidade abandonada - onde os espaços de vida públicos desapareceram.

A cidade recuperada - onde grandes esforços são feitos para encontrar um novo equilíbrio entre os usos da cidade como lugar de encontro, comércio e circulação (GEHL; GEMZØE, 2000, p. 14).

As cidades mudaram com o tempo e as mudanças trouxeram novas ambiências e novos modos de viver para os espaços públicos. Estes fatores estão relacionados às questões econômicas, acesso à informação, novas tecnologias, globalização das práticas culturais e territoriais. Outro fator considerado importante é o da mobilidade (cultura da velocidade), o qual mudou as percepções de deslocamento e questões de espaço/tempo, e ainda fragmentou a cidade com as áreas de passagem, transformando os lugares em 'não lugares', refletindo na noção e no sentido de lugar (FORTUNA, 2002; MATOS, 2010).

A ideia de multiculturalismo nas cidades e a interação entre diferentes pessoas de grupos sociais distintos (idade, classe social, nível de escolaridade, etnia), desloca o debate acerca dos espaços públicos para um viés sociológico, promovendo um debate relativo à questão de: espaços públicos para quem?

[...] o espaço público adquire outras dimensões e valorizações, sendo apropriado de forma diversificada, pois as práticas sociais também se diversificam, multiplicam-se as escolhas, os papéis e identidades, em que ganham força outras dimensões mais subjectivas. Os espaços públicos de vizinhança perdem força a favor de outros espaços em que a imagem e o simbolismo é mais valorizado. Muitos destes espaços cuja qualidade tem vindo a ser melhorada, contribuem, não só, para melhorar a imagem e qualidade de vida da cidade, como propiciam espaços de difusão do conhecimento, de animação, de encontro com a natureza, de expressão artística e promoção de eventos, para usufruto quer da população residente, quer da que utiliza a cidade, nomeadamente os turistas (MATOS, 2010, p. 31-32). 
Alves et al. (2004) afirma que quando a proposta física para o espaço público não está em consonância com as aspirações da comunidade, os ambientes tornam-se ociosos e abandonados. Este fato é muito comum nos centros das cidades, onde o espaço público encontra-se próximo a locais de comércio e com poucas residências.

Jacobs (2000) defende que para um bom espaço público, há a necessidade da heterogeneidade de usos, pessoas e atividades; moradores e pessoas frequentadoras desses espaços não podem ser padronizadas, existe uma multiplicidade de questões quando se fala de seres humanos, para tal, estes espaços devem trazer a vitalidade, promovendo encontros diversos, ações espontâneas e a pluralidade de atividades conforme seus frequentadores.

Karssenberg e Laven (2015) colocam como ponto essencial para um bom projeto de intervenção na cidade o conceito de plinths, ou seja, o andar térreo dos edifícios, aquilo que está na escala visual do que diretamente enxergamos nas ruas, é a nossa relação direta com as construções quando percorremos as cidades. Os plinths são importantes para criar um ambiente vivo que traga uma boa experiência para quem percorre o espaço público. Além disso, quando bem pensado traz consequências positivas a cidade, como segurança e atratividade para o ato de caminhar e vivenciar os espaços, por exemplo. Segundo alguns pesquisadores, quando se fala em áreas comerciais e residenciais que possuem um bom projeto de plinth, tornando o local seguro, limpo e de fácil compreensão, os pedestres permanecem ali por até três vezes mais tempo do que em uma estrutura sem estas características (KARSSENBERG; LAVEN, 2015).

Nas últimas décadas alguns estudiosos voltaram-se para a questão da humanização do espaço urbano. Para atingir tal objetivo, complexo e sujeito a uma gama de interpretações, Gehl (2015) traz alguns critérios para determinar um bom espaço público, fruto de anos de estudos e observações de espaços públicos ao redor do mundo, e como produto dessas análises, alguns critérios para a requalificação das cidades devem ser atendidos.

No espaço público assim como em uma casa, as atividades acontecem muitas vezes de forma simultânea, quem utiliza a cozinha não impede que outra atividade seja realizada na sala de estar. Gehl (2008) reforça que, quando no espaço público há um público expressivo ou acontece algo significativo, a tendência é que se incorporem mais pessoas e as atividades naquele espaço cresçam tanto na duração quando na extensão. Sendo assim, a vida nesses espaços é um processo que reforça a si mesmo. Ainda, a questão do número de pessoas e o tempo que elas permanecem no espaço é outro fator importante para o reforço da vitalidade dos espaços públicos.

Em última análise, tanto na Europa quanto na América Latina, o perfil das cidades e seus espaços vêm se modificando a medida que, cada vez mais, se inserem no contexto econômico global. Como contrapartida, existe uma revalorização das forças culturais, artísticas e históricas das comunidades e uma busca de reafirmação de suas identidades dentro deste contexto. Juntamente a estes processos, nota-se uma união entre os agentes públicos e privados em busca de trazer espaços públicos qualificados destinados ao consumo cultural, numa política indissociável ao ato de dar novos usos a estes locais segundo os critérios do mercado e as novas dinâmicas sociais (MEDINA; ÁLVAREZ, 2009). 


\section{METODOLOGIA}

Empregou-se a pesquisa qualitativa para o entendimento teórico das questões referentes ao espaço público e a sua inserção no meio urbano. Somado a isso, quando se refere aos objetivos, com o intuito de compreender o tema de forma aprofundada e familiarizando-se com o problema em questão, utilizou-se da pesquisa bibliográfica, envolvendo o levantamento da literatura pertinente (GERHARDT; SILVEIRA, 2009).

O espaço foi analisado in loco tendo em pauta quatro dimensões: a física, a funcional, a social e a histórico-cultural (ALVES, 2003). Dentro destes parâmetros foram elencados as qualidades e características do local para cada elemento. Os pesquisadores, através da pesquisa quantitativa sem interação com o usuário (método observação direta), analisaram o sítio e os usuários durante o período da manhã, tarde e noite, utilizando-se de apontamentos e fotografias, descrevendo interações e atividades no local.

Somado a isso, empregou-se uma survey, pesquisa quantitativa de interação com o usuário, para a formulação e aplicação dos questionários. As entrevistas survey, segundo Zamani, Lee e Pippi (2014), são uma excelente ferramenta de inquérito para uma gama ampla de temas, ou seja, sobre as preferências de uso, os tipos de atividade, os hábitos e sugestões para a área de estudo em questão.

As perguntas foram cuidadosamente estruturadas a partir do método selecionado e ordenadas segundo eixos temáticos referentes ao espaço de uso coletivo, que abrangem: o porquê do uso, a frequência de uso, o tempo de uso, com quem usam, como interagem com pessoas conhecidas e desconhecidas, o tipo de interação que ocorre com ambos, o quanto acham importante sociabilizar com pessoas conhecidas e desconhecidas, o quanto estão satisfeitas com o espaço e por fim as características que mais e menos gostam em toda a área de convivência.

O inquérito continha 10 perguntas de múltipla escolha, referentes a temas como: características do usuário (idade e sexo), sua proveniência; como em que horários e dias da semana utiliza-se do espaço público, bem como os fatores que os desagradavam ou eram de interesse e influenciavam na utilização. Uma última pergunta era livre e questionava, caso tivessem algum ponto a declarar, o que mudariam no espaço em questão.

As entrevistas foram aplicadas em quatro dias, nos períodos da manhã, tarde e noite. Adotou-se a preferência pelos três turnos, pois segundo Madden (2001), este modo de aplicação do survey permite o contato com uma variedade maior de usuários, alcançando assim um raio mais abrangente de atividades possíveis no espaço. Este método, ainda segundo Madden (2001) permite a noção do contexto de um conjunto de pessoas e as opiniões pessoais a partir das perguntas abertas que completam as de múltipla escolha. 


\section{ANÁLISE}

\section{Contexto}

A cidade do Porto, situada no Norte de Portugal, é um dos concelhos mais populosos do país (Fig. 1). O território, segundo dados do AMP (2011), é composto por sete freguesias em uma área de $41,4 \mathrm{~km}^{2}$, com 237.591 habitantes, dos quais aproximadamente $23 \%$ apresenta mais de 65 anos de idade, o que evidencia um alto índice de envelhecimento da população local.

Figura 1: Vista aérea da cidade do Porto e seu perímetro urbano.

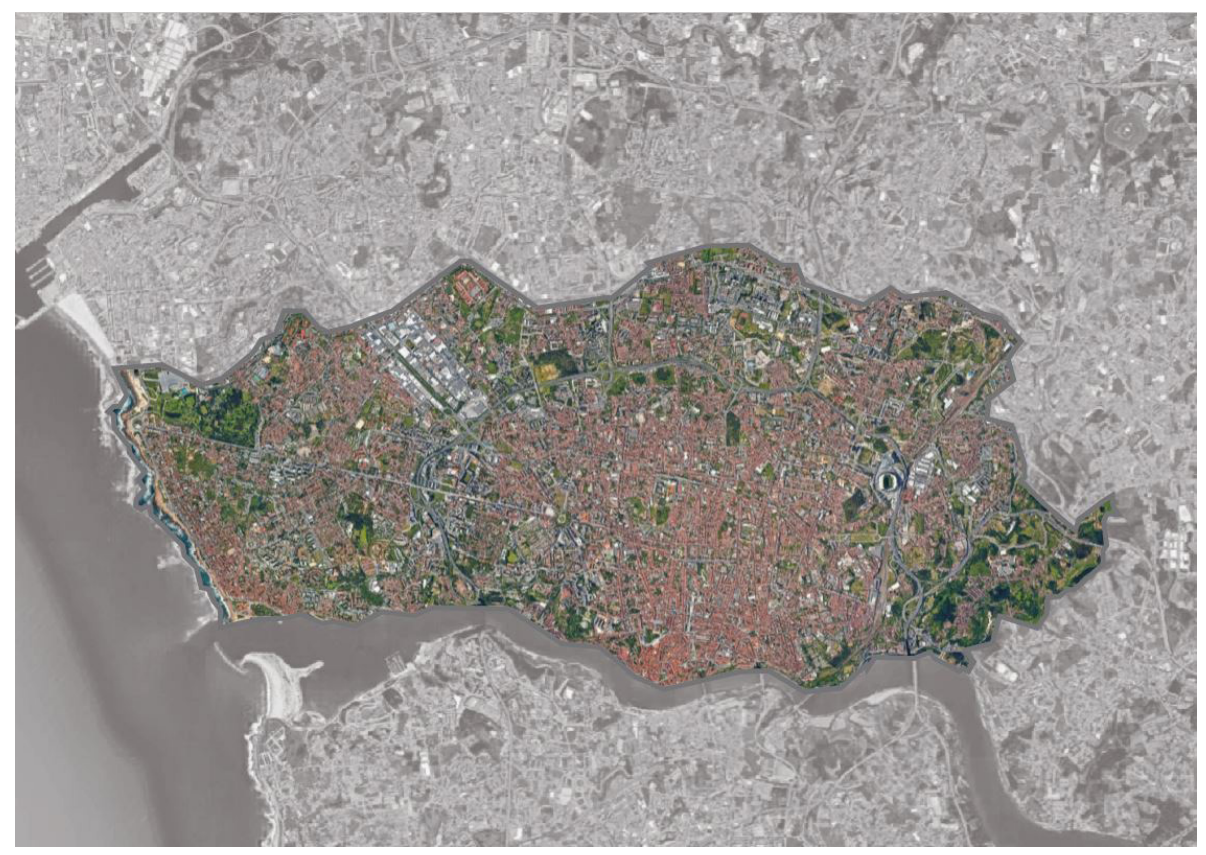

Fonte: modif. Google Maps, 2019.

O concelho, que é muito conhecido pelo famoso Vinho do Porto, tem seu centro histórico reconhecido desde 1996 pela Unesco como Património Cultural da Humanidade, por isso conserva notáveis monumentos e herança histórica e cultural. Com intervenções e modernizações de alguns de seus espaços públicos, em conjunto com novas infraestruturas e acessibilidades, o Porto foi inserido nos roteiros da Arquitetura Moderna, atraindo assim muitos visitantes e enquadrando a cidade como Melhor Destino Europeu.

\section{Dimensão física}

No exterior da cidade medieval, a oeste da muralha gótica e no limite da encosta que mergulha no Douro, encontra-se o Passeio das Virtudes (Fig. 2), um espaço público dividido em três partes: a primeira está relacionada ao passeio público conectado às edificações; a segunda refere-se à via de veículos e seu estacionamento; e a última aos gramados de contemplação (Fig. 3). 
Figura 2: Localização do Passeio das Virtudes, cidade do Porto.

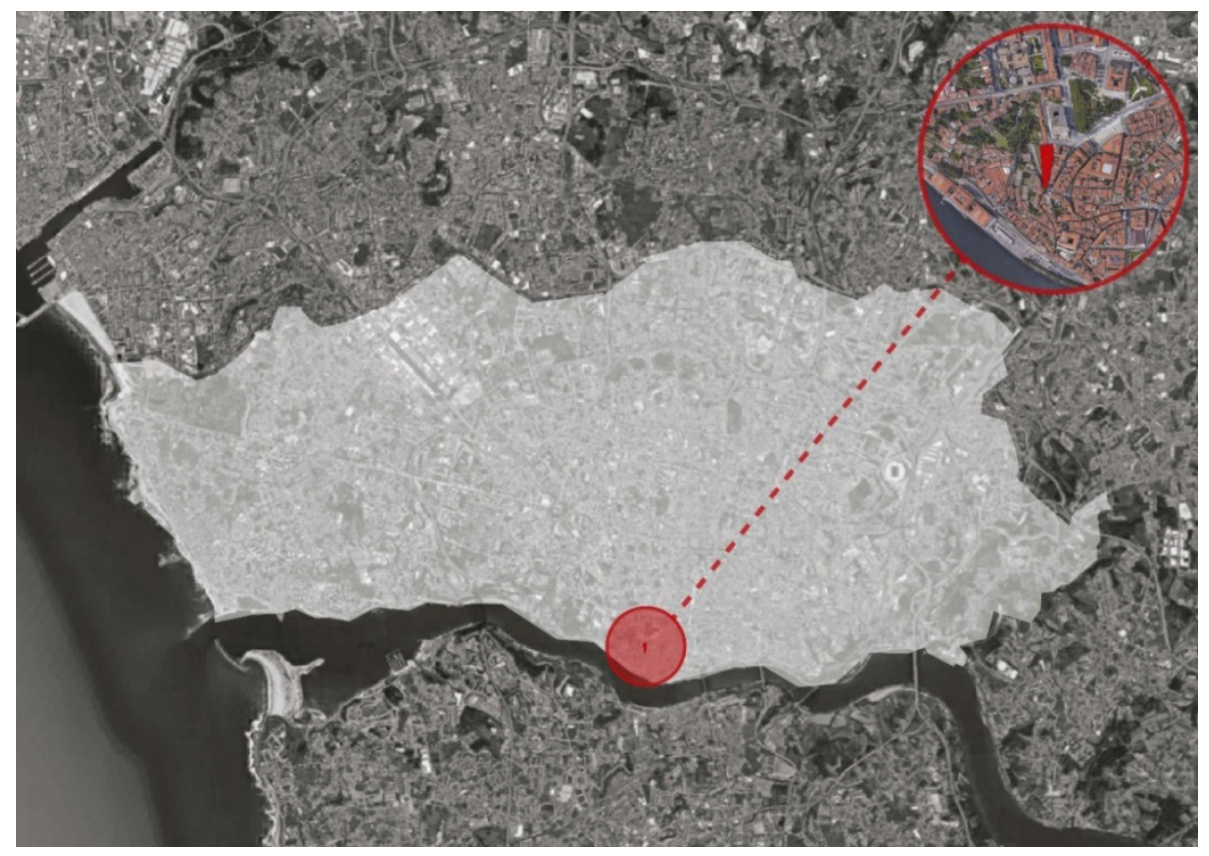

Fonte: modif. Google Maps, 2019.

Quando se analisa o espaço público como um todo se nota a ausência de um desenho urbano ou elementos paisagísticos que conectem todos os espaços e torne a leitura do local em um só contexto. Somado a este fator, o uso variado de materiais (pedra paralelepípedo, saibro e gramíneas), sem linguagem de cor e um aspecto contínuo, torna o espaço visualmente fragmentado. Em relação a forma proporcionada pelo layout, o comprimento da praça é maior que sua largura, portanto, é mais estreita e linear. Sendo assim, este fato torna os elementos físicos e compositivos mais próximos, em uma escala mais humana. Os elementos fragmentados do espaço contribuem para que o mesmo não pareça muito grande e vazio.

O passeio público tem relação direta com o espaço edificado, conformado por lote estreito e comprido, característico da cidade do Porto. Ou seja, é o primeiro contato dos edifícios comerciais e residenciais com a rua, sendo este o local com pouca circulação de pessoas. Ademais, possibilita a permeabilidade pedonal no espaço para as pessoas advindas do Centro Histórico da cidade, de áreas comeciais e turísticas importantes, como Jardim da Cordoaria, Torre dos Clérigos, Praça de Lisboa e Aliados. Além disso, o passeio público não apresenta elementos ou monumentos que conformam pontos focais ou que deem caracterização específica ao percurso. Os prédios adjacentes ao espaço não possuem recuo, são alinhados entre si, e como de forma geral apresentam a mesma altura e muitas vezes desenho de fachada parecido, tornam-se um bloco monolítico, um conjunto homogêneo da frente urbana. 
Figura 3: Mapa mostrando a divisão do espaço em ambiente construído no Passeio das Virtudes. Em marrom, edificações; em bege e cinza, espaços de circulação; em verde, gramados de contemplação.

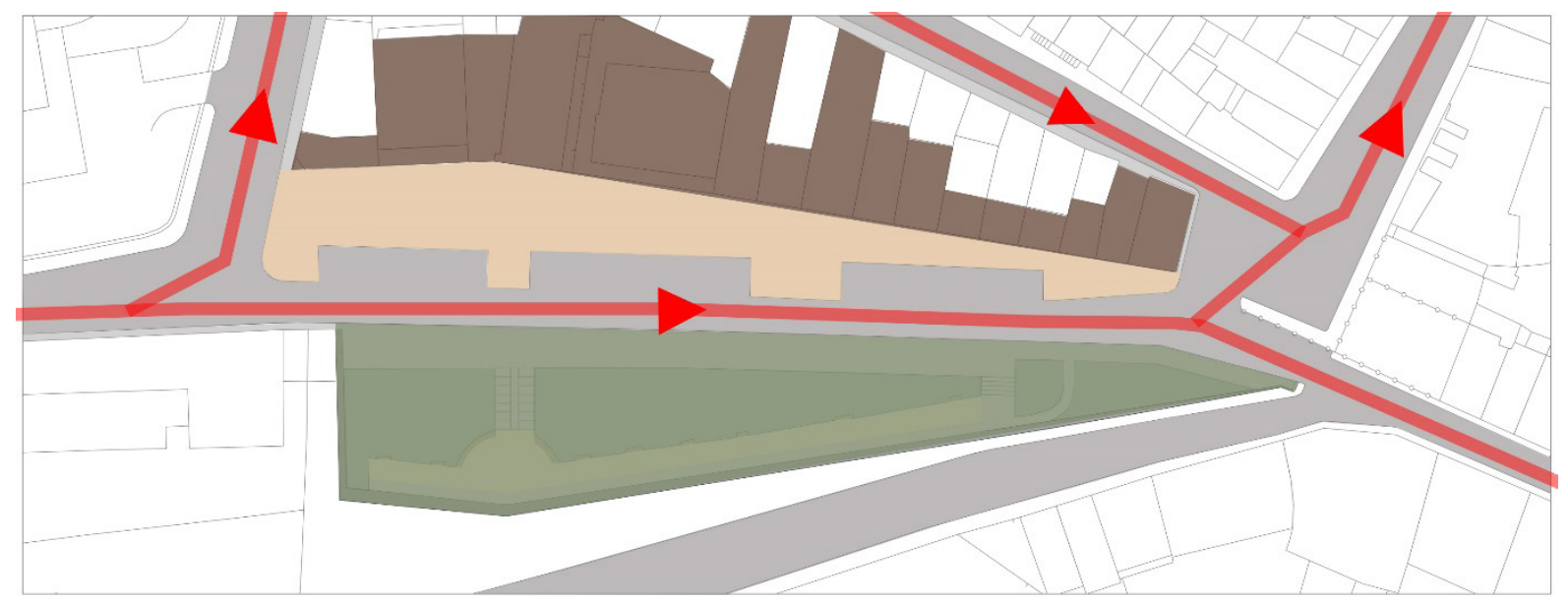

Fonte: dos autores.

Segundo Quaresma et al. (2017) a origem dessa conformação arquitetônica similar e sem variações pode ter origem na manutenção de soluções arquitetônicas correntes, existência de um mesmo proprietário ou construtor para vários lotes, entre outros fatores. Destaca-se a Escola Artística e Profissional Árvore, que se distingue pelo seu lote e logradouro extensos. Assim, não há uma edificação de destaque, ou seja, com formas ou características arquitetônicas que proporcione um diferencial na morfologia urbana. A conformação morfológica, portanto, estabelece uma barreira de edificações, a leste do Passeio das Virtudes, as quais barram a permeabilidade visual e física do espaço a partir da região dos Clérigos e da Rua Dr. Barbosa de Castro (Figs. 4 e 5).

Figuras 4 e 5: Relação das edificações com as áreas livres e a Rua de Azevedo de Albuquerque.

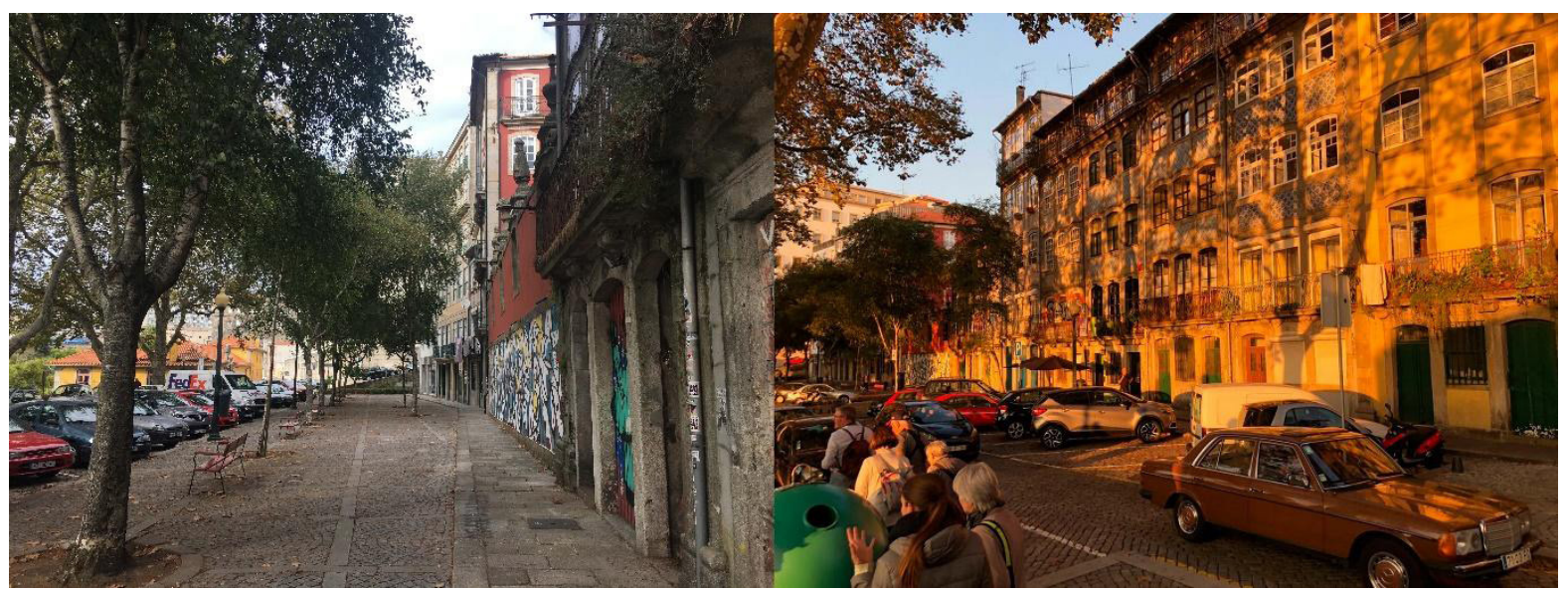

Fonte: Arquivo pessoal.

Já a via que divide e fragmenta o espaço (Figs. 6 e 7) é composta por apenas uma faixa de circulação de veículos e por um estacionamento localizado em ambos os lados. 
Figuras 6 e 7: Rua Passeio das Virtudes.

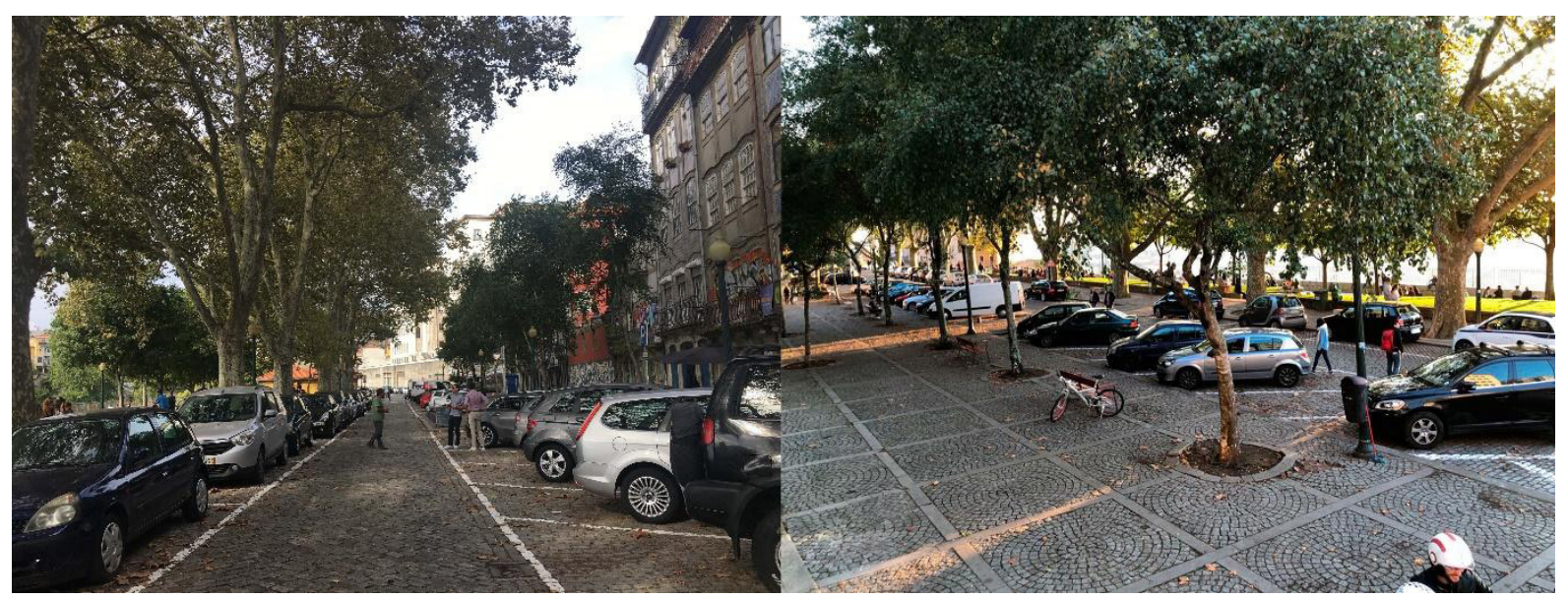

Fonte: Arquivo Pessoal.

O espaço de forma geral é pouco permeável, havendo a leste o quarteirão denso e fechado por edificações, e a oeste o declive do terreno juntamente com o parque em direção a Baixa do Porto, não permitindo que o espaço seja acessado por esta área. A forma de acesso ao Passeio das Virtudes é o mesmo para carros e para pedestres, pelo Norte, através da Rua De Azevedo de Albuquerque e da Rua de Dr. Antonio de Souza Macedo, e pelo Sul, através da Rua das Virtudes.

Na área de gramados com vista para o Douro há maior intensidade de uso público, maior número de pessoas e utilização em diversas horas do dia (Figs. 8 e 9). Inexistem neste espaço elementos construtivos de grande porte ou com importância monumental tampouco variedade de mobiliário urbano, apenas poucas mesas fixas e bancos, ou até mesmo as muretas do gramado sendo usadas como bancos. O lazer passivo em grupos é predominante, pois o local é conhecido entre os jovens como um espaço para apreciar o pôr do sol.

Figuras 8 e 9: Gramado de contemplação com inclinação para a vista do Rio Douro.

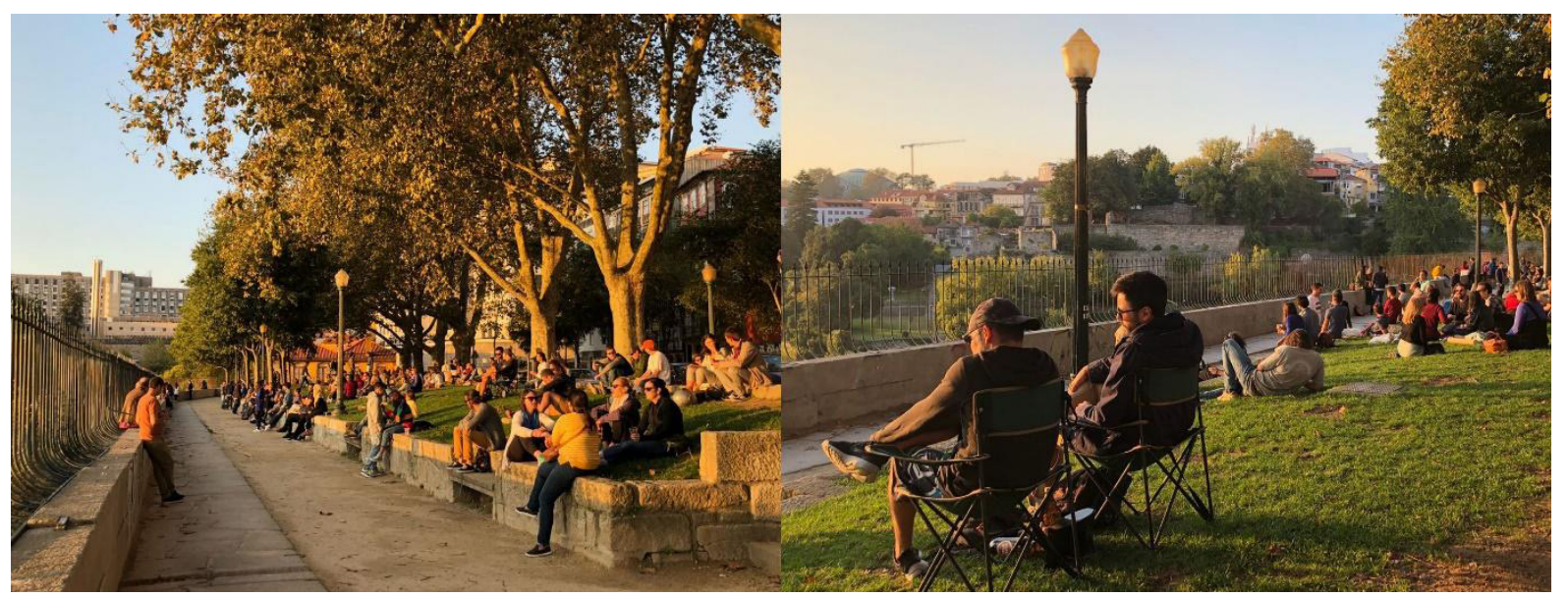

Fonte: Arquivo pessoal. 
Na paisagem do Passeio das Virtudes (Figs. 10 e 11) há características geomorfológicas singulares proporcionadas pelo rio, pela escarpa e pela malha complexa da Baixa do Porto. A partir dos gramados encostados ao exterior da muralha cria-se um elemento que caracteriza e estabelece legibilidade do espaço perante os demais da cidade; ou seja, o enquadramento da paisagem é um elemento físico que estabelece um ponto de referência especifico dentro do contexto urbano. Como o espaço dos gramados não possui grandes elementos construtivos, permite assim usos abrangentes e variados, além da apropriação pelos usuários para além do lazer passivo.

Figuras 10 e 11: Enquadramento da paisagem símbolo do Porto a partir dos gramados do Passeio das Virtudes.

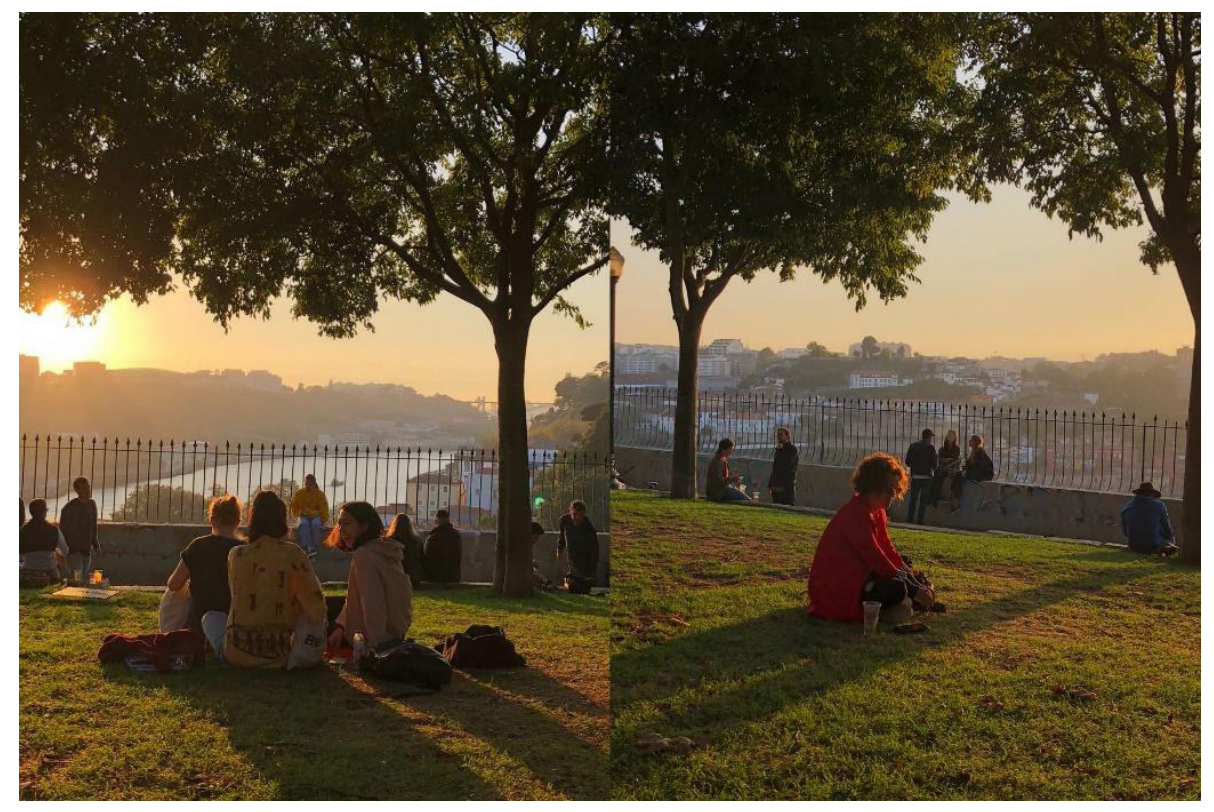

Fonte: Arquivo pessoal.

O Passeio das Virtudes possui abundância de árvores de grande porte que permitem sombreamento durante o verão, amenizando a temperatura e permitindo a entrada indireta de luz sem barrar a vista da paisagem. Já durante o inverno, as caducifólias permitem a entrada de luz solar com a queda das suas folhas. Ademais de proporcionarem conforto térmico, as árvores do Passeio das Virtudes são também importantes pela capacidade em atrair e manter fauna silvestre, uma característica apreciada por usuários de espaços públicos (RUMBLE et al., 2019).

\section{Dimensão funcional}

A divisão física do espaço público em três partes também se reflete funcionalmente na área. A primeira parte do espaço, a calçada, torna-se local de função para atender a circulação geral de pedestres, conferir acesso aos prédios, seja para a área comercial quando para a residencial, bem como dar continuidade a circulação de pedestres advindos de outros espaços da cidade. Esta área não possui muito fluxo de pessoas e também não há 
permanência de público por muito tempo, sendo raros os momentos em que se observou pessoas utilizando o mobiliário ali presente. À noite esta zona parece estar abandonada, pois não há apropriação dos espaços e o comércio já está fechado, tornando-se algo perigosa.

As tipologias das edificações, as quais são existentes apenas junto ao passeio público, possuem base comercial conectada diretamente à área pública e demais pavimentos residenciais. Esse fator torna o espaço robusto com potencialidade de transformação de funções ou estímulo de funções mistas, uma vez que o mesmo não é ativo ou muito utilizado. As funções comerciais e de serviços instaladas são: adega, café, escola e loja de produtos gerais. Sendo assim, de forma geral, parecem estar com pouca concordância com o uso residencial e de lazer da área. As funções ali exercidas não estabelecem legibilidade por algum serviço ou comércio específico, portanto, conforme as observações, não estimulam fluxo e aglomeração de pessoas nestes espaços. Existem ainda edificações abandonadas, que no estado atual degradam o espaço e não promovem atividades junto ao passeio, porém tornam-se espaços edificados livres para novas potenciais atividades (Fig. 12).

Figura 12: Mapa de configuração dos usos das edificações e dos espaços livres.

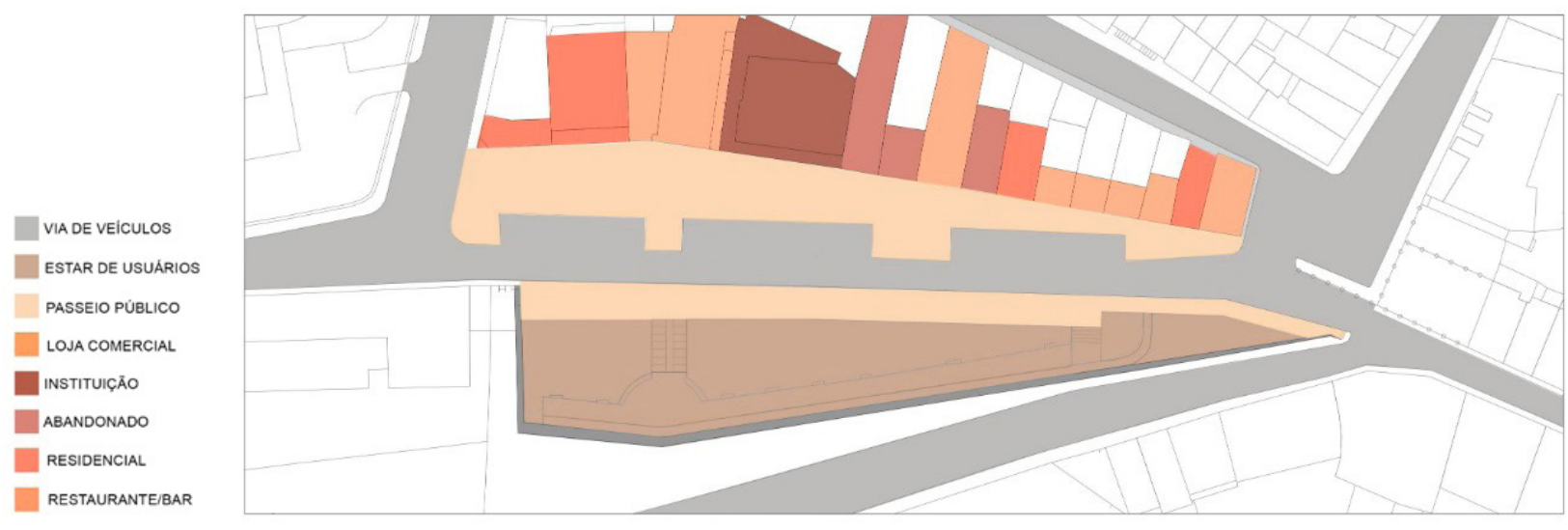

Fonte: os autores.

A segunda parcela do espaço, a via, tem a função de conduzir os automóveis até a área e oferecer vagas de estacionamento para veículos no geral - pessoas que se deslocam para apreciar os gramados, para os moradores ou para o acesso ao comércio. A via de forma geral não apresenta fluxo intenso, entretanto os estacionamentos estavam sempre ocupados em diversos momentos do dia. Os automóveis estacionados no local criam uma barreira visual e física que fragmenta os elementos do espaço público.

Outro modo de acessar o espaço é através do transporte público (Fig. 13), com autocarros que conectam diversas zonas da cidade. A paragem mais importante, próxima a região dos Clérigos, é a denominada Jardim da Cordoaria $(240 \mathrm{~m} / 4 \mathrm{~min})$. O metrô mais próximo é a linha D da estação São Bento $(850 \mathrm{~m} / 4 \mathrm{~min})$. Pelas ruas Dr. António de Sousa Macedo, Dr. Azevedo de Albuquerque, Francisco da Rocha Soares e Rua das Virtudes, pode-se acessar a pé ou de carro. 
Em resumo, a circulação de automóveis é bem estruturada em detrimento da pedonal, sendo que essa última, quando se analisa o acesso a zona a partir das demais áreas da cidade, torna-se prejudicada para pessoas com mobilidade reduzida - idosos, cadeirantes, crianças, etc., devido ao forte declive em direção ao Passeio das Virtudes.

Figura 13: Mapa destacando os meios de mobilidade e acesso ao Passeio das Virtudes.

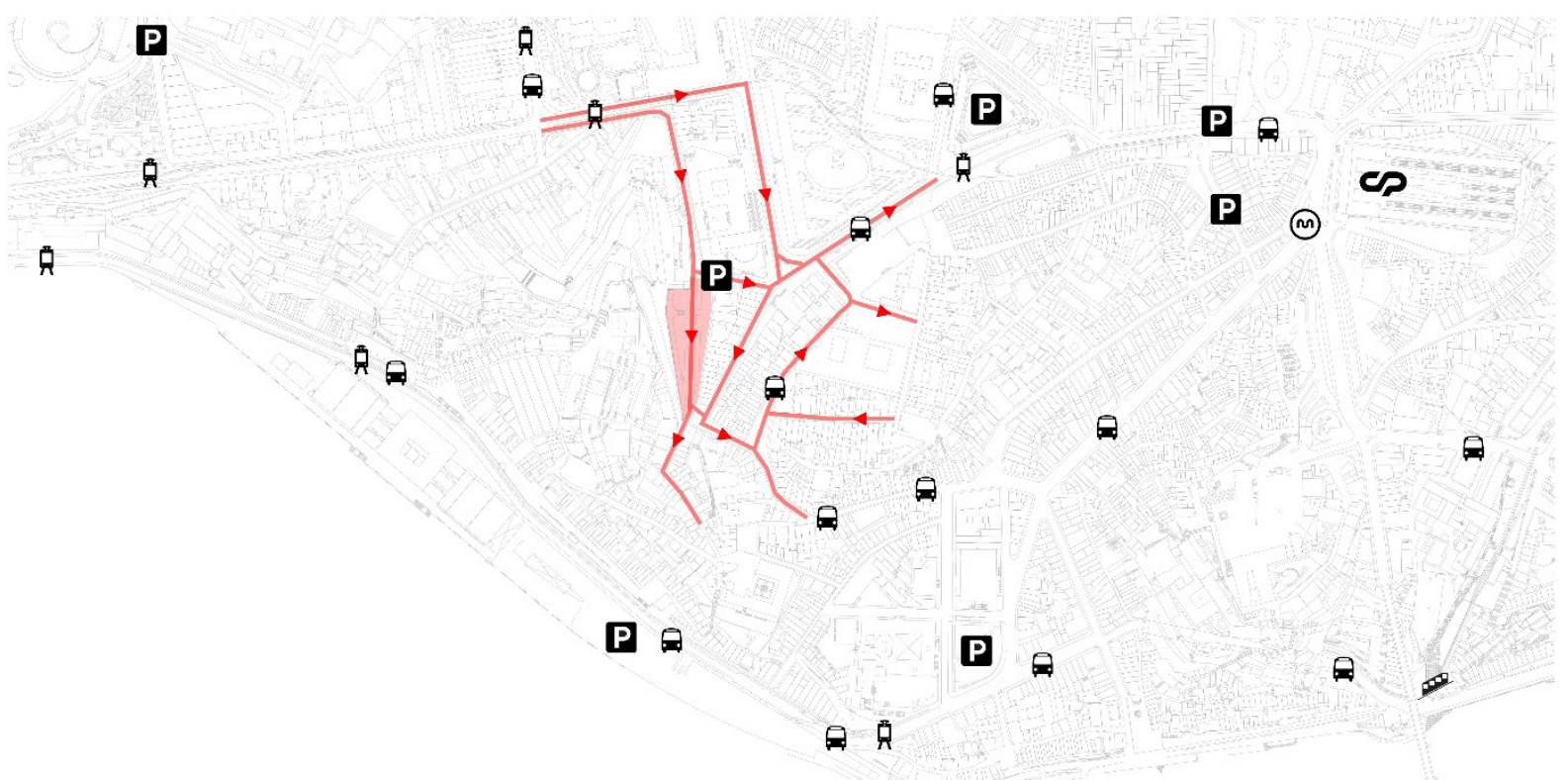

Fonte: os autores.

A terceira parcela do espaço, o gramado de contemplação, é o local com maior intensidade de uso, com aglomeração de pessoas, geralmente em pequenos e médios grupos onde os jovens são o maior público, em lazer passivo e consumo de bebidas. Inexistem outras funções pré-assumidas ali, ou estruturas que estimulem o lazer ativo, como quadras para jogos ou eventos, por exemplo. Os gramados são livres, levemente elevados e atribuem o uso do sentar-se e do contemplar como função de essência.

Para o acesso aos gramados existe uma elevação que conforma o desenho de paisagismo, o qual não apresenta relevância de desenho ou forma. $\mathrm{O}$ fato de existir desnível na área dos gramados de contemplação em relação aos demais espaços, condiciona inacessibilidade para pessoas com mobilidade reduzida ou crianças.

\section{Dimensão social}

O uso para lazer passivo, as condições topográficas e da paisagem condicionam diretamente as questões sociais na área (Figs. 14 e 15). O público se desloca para o local especificamente para apreciar o pôr do sol junto à vista do Rio Douro e frente ribeirinha de Vila Nova de Gaia, o que diferencia e destaca o espaço público em relação a outros da cidade do Porto. 
Figuras 14 e 15: Apropriação do espaço para o evento do pôr-do-sol.

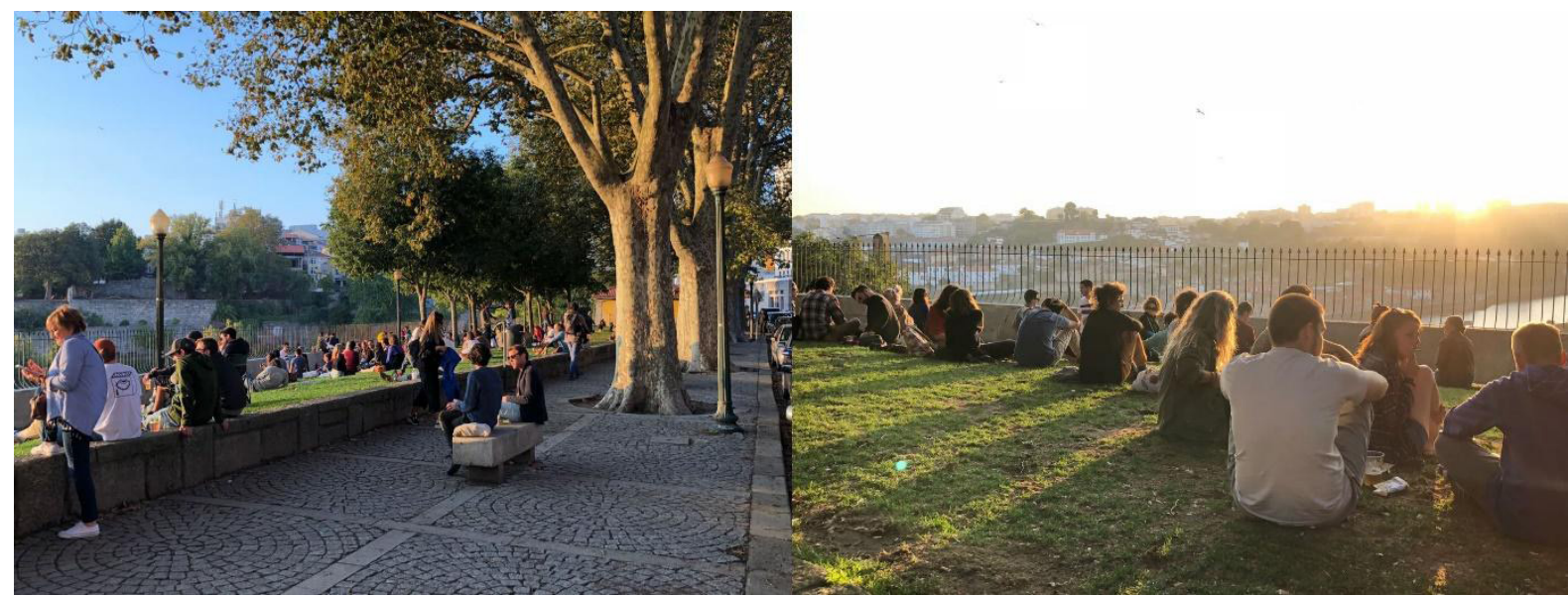

Fonte: Arquivo pessoal.

Sendo assim, o local, mais especificamente no fim do dia, torna-se espaço de reunião de grupos de pessoas, jovens em sua maioria, em grupos interagindo entre si ou somente de forma visual com outros grupos, como espaço de encontro e divertimento, utilizandose a cidade como cenário. Há artistas plásticos que frequentam a área para aproveitar-se do belvedere e pintar.

O consumo de bebidas e alimentos é feito a partir de poucos bares localizados a leste dos gramados. Nas demais regiões do passeio público próximo as edificações não há muitos usos comerciais/serviços, ou os que ali existem funcionam em horário comercial e não atendem as demandas do público e atividades dos espaços (Figs. 16 e 17). No verão as atividades se estendem até mais tarde e nos fins de semana.

Figuras 16 e 17: Fachadas com atividades em pontos específicos e passeio público sem movimentação.

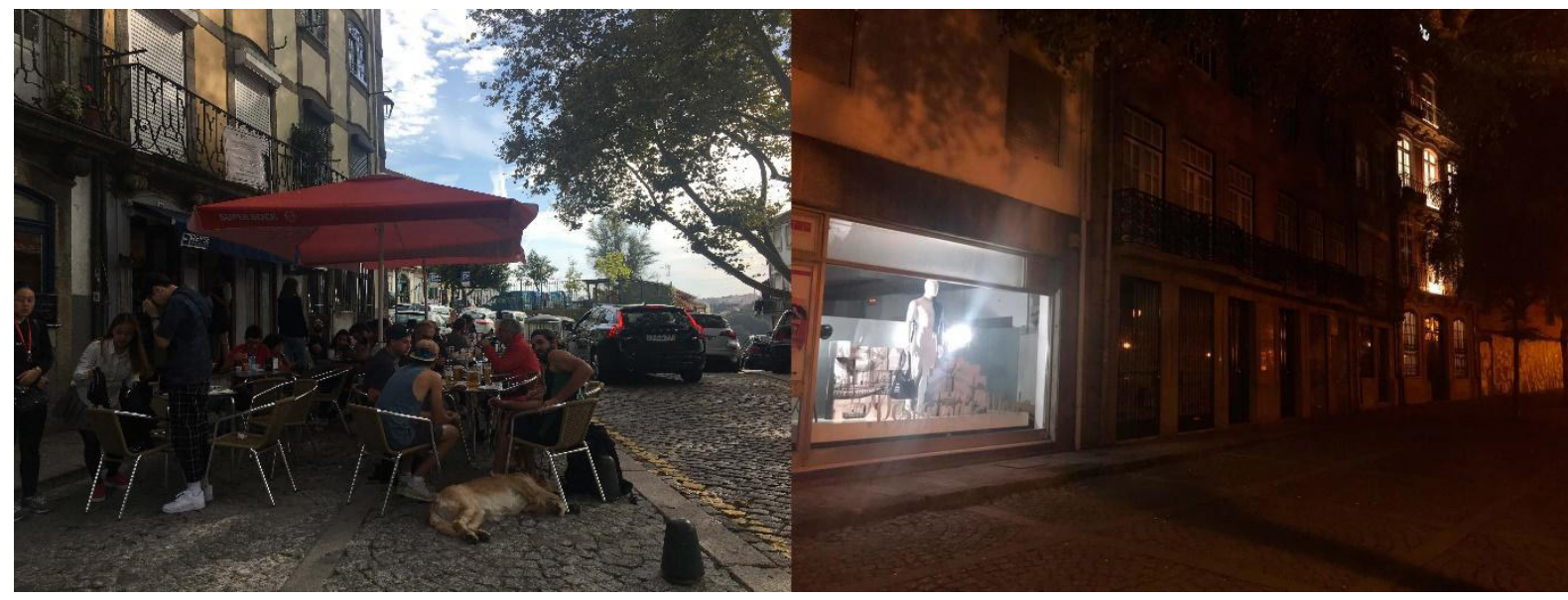

Fonte: Arquivo pessoal.

Constata-se que os usos atuais dos térreos das edificações, para comércio e serviços, não propiciam a interação entre a população efêmera e os moradores locais. Cabe citar que o fechamento do comércio ao anoitecer, somado ao bloqueio visual e físico causado pelos estacionamentos da via resulta num espaço pouco frequentado e perigoso a noite. 
Quanto à acessibilidade a social do Passeio das Virtudes pode-se dizer que o espaço é um local democrático. Apesar dos jovens predominarem como público no local, em diversos momentos do dia também pode ser verificada a presença de idosos, crianças e turistas. Este fator revela uma grande oportunidade de relações intergeracionais. Somado a isto, a forma e estrutura do espaço dos gramados não conduz a um uso específico em detrimento de outros, tornando o espaço público um local neutro e que possibilita atividades para todas as gerações e grupos sociais.

A predominância do gênero masculino ficou evidente em diversos momentos de observação a partir dos pesquisadores. A classe social, por sua vez, não é um fator que possa ser entendido ou determinado apenas por observações, portanto, não foi detectada.

\section{Dimensão cultural e histórica}

O nome do local tem origem na crença de poderes relacionados a cura que a água da fonte possuía, possivelmente poderia ter existido no local uma imagem da Nossa Senhora das Virtudes. Sendo assim, o nome Virtudes passou a designar toda a zona e seus elementos construtivos (QUARESMA et al., 2017).

No entorno imediato, a declividade permitiu o terraceamento da superfície o que, juntamente com as ótimas condições climáticas do lugar, originou a Quinta das Virtudes, um centro de produção de plantas. Este horto chegou até o século XX e foi desenhado pelo famoso horticultor José Marques Loureiro (BARREIRA; ROSAS; BOTELHO, 2017; QUARESMA et al., 2017). Posteriormente, o horto foi transformado em Jardim Público pela Câmara Municipal do Porto. O Passeio das Virtudes, incluindo a área edificada e os Jardins, constitui o único espaço verde classificado como Património Mundial (BARREIRA; ROSAS; BOTELHO, 2017; QUARESMA et al., 2017).

O Passeio das Virtudes era considerado um importante centro social da alta sociedade do Porto, frequentado por pessoas com importância social como os desembargadores da Relação, que ficava próximo dali, na Cordoaria e as meninas das mais notáveis casas de mercadores do burgo (SILVA, 2016). Entretanto, a configuração que a cidade assumiu no final do século XIX, na qual já não havia muralhas, e o redirecionamento da centralidade do Porto para a Praça da Liberdade, acarretou o isolamento da zona das Virtudes. A cidade de certa forma voltou-se de costas ao local tornando o seu acesso escasso e difícil, fato este que contribui para a sua decadência a partir do início do século XX.

Muitas intervenções visaram alterar e ou revitalizar as funções do local (QUARESMA et al., 2017) e a primeira, no fim do século XVIII, foi conduzida no paredão que sustenta a plataforma do Passeio das Virtudes. Teve como mandante Rodrigo António de Abreu e Lima, na época juiz da Alfândega, e foram atribuídas a Francisco de Almada e Mendonça, desembargador, corregedor e provero da Comarca do Porto, o qual fomentou diversas obras públicas pela cidade do Porto. (BARREIRA; ROSAS; BOTELHO, 2017; QUARESMA et al. 2017). 
Com a intenção de melhorar o espaço urbano, já no século XIX, é realizado o projeto de nivelamento da Calçada das Virtudes, a qual liga o Passeio das Virtudes e a antiga cidade intramuros à Fonte das Virtudes. Foi nesta intervenção que o Jardim das Virtudes se tornou de alameda para passeio, isto é, em Jardim Público fechado, atendendo as necessidades da sociedade portuense da época.

Nos anos de 1911, 1930 e 1935 a zona do Passeio das Virtudes e o largo junto as casas recebem ajardinamento, decorações e embelezamentos, sendo estes realizados não somente pela câmara, mas também pela Direção dos Serviços de Jardins, Arvoredos e Cemitérios (BARREIRA; ROSAS; BOTELHO, 2017).

Após ter sido adquirida pela Câmara Municipal do Porto, o Jardim foi restaurado em 1998, onde foram arrelvados os socalcos, ligados por uma escadaria, e árvores e arbustos, alguns seculares, foram conservados.

No jardim permanecem bancos e varandins, em betão, imitando troncos de árvores, como também vestígios do carapinhado que revestia muros e pequenos 'rochedos', também em betão, para crescimento das plantas. Cabe ainda destacar, outra vez, que todo esse declive no Jardim leva a exuberantes vistas sobre o Rio Douro e o Porto ribeirinho.

Por fim, cabe citar duas edificações que abrigam instituições importantes, a Cooperativa Artística da Árvore e Escola Artística e Profissional Árvore. A primeira tem sua sede no edifício que teve ordem de construção por José Pinto de Meireles, inaugurado em 1763, o qual foi adquirido pela Cooperativa em 1989. A casa tem vista privilegiada do Douro e do Jardim das Virtudes. A Árvores (Cooperativa de Actividades Artísticas CRL) é uma cooperativa no âmbito cultural que funciona como um organismo privado de utilidade pública. Foi fundada em 1963 por artistas, escritores, arquitetos, e intelectuais, os quais estavam interessados em novas condições para a produção e difusão cultural, sendo esta de forma livre e independente. Por fim, a "Árvore tem como objeto a produção, divulgação e comercialização de obras artísticas e editoriais e a formação e informação dos sócios e do público em geral na área das artes visuais, dos estudos de arte e em outras áreas da criação e do saber" (ÁRVORE - COOPERATIVA DE ACTIVIDADES ARTÍSTICAS, 2018).

Ligada a Cooperativa, a Escola Artística e Profissional Árvore inicia-se nos anos 1970, com a abertura de cursos livres em expressões plásticas. A Escola da Árvore é, portanto, uma escola profissional que tem a educação centrada na cidadania ativa e para o desenvolvimento de formações em áreas que exigem competências artísticas (ÁRVORE ESCOLA ARTÍSTICA E PROFISSIONAL, 2018). Por fim, ambas as edificações são marcos na paisagem e referência cultural conectada ao Passeio das Virtudes. Entretanto, em diversas visitas não se notou eventos ou a apropriação das mesmas nos espaços livres das Virtudes.

\section{Análises a partir da aplicação do survey}

Dos entrevistados, $42 \%$ responderam que visitam o local para apreciar a paisagem. $\mathrm{O}$ pôr-do-sol é o grande espetáculo procurado, pois 68\% apontaram ir ao local no entardecer (Fig. 18). 
Figura 18: razões de utilização do espaço e em quais horários.

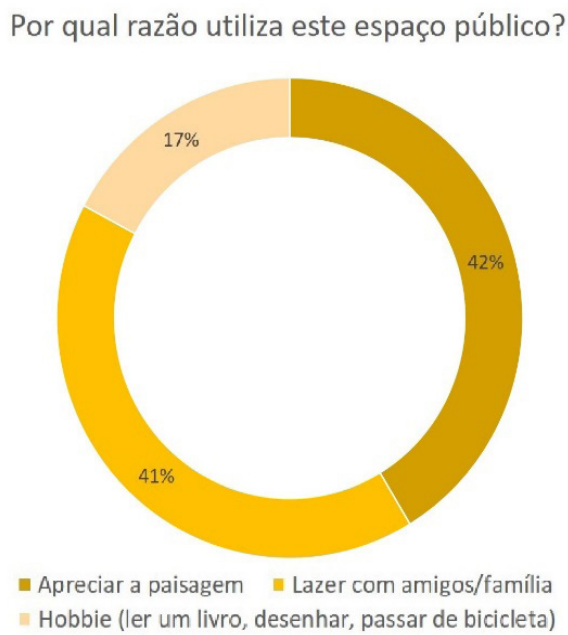

Fonte: os autores

Complementando este fato, a maioria de visitantes vai em grupos, para lazer, mostrando que é um lugar de interação e que os integrantes dos grupos são conhecidos entre si, sendo famílias ou grupo de amigos. Entretanto, existe uma expressiva quantidade de pessoas que visitam o local sozinhas, vão para relaxar e admirar a paisagem apenas. Os usuários se distribuem igualmente entre homens e mulheres, mas adultos são os maiores frequentadores (Fig. 19).

Figura 19: Número de pessoas que utilizam o espaço, por gênero e idade.
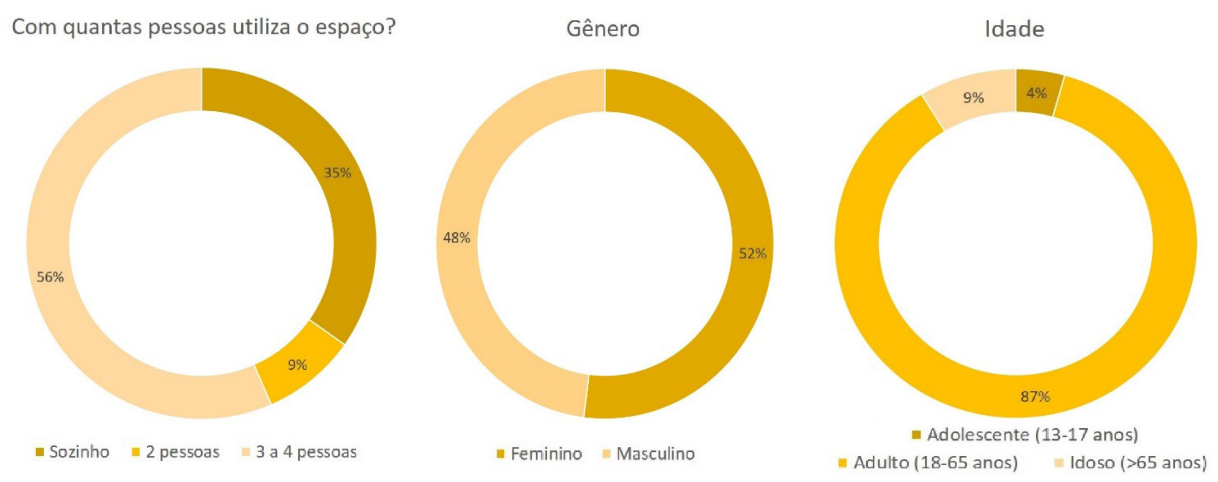

Fonte: os autores.

Quando perguntados sobre o que mudariam no local, muitos mencionaram a ausência de eventos no espaço, bem como a ausência de limpeza. Muitos apontaram alguns elementos a serem mudados como questões de limpeza, iluminação, mobiliário urbano, entre outros. Entretanto, na maioria dos inquéritos os participantes não acreditavam que o lugar precisasse de mudanças de grande porte, eram apenas detalhes que se somariam as potencialidades inerentes e naturais ao espaço.

Um ponto limitante da análise é o fato de as entrevistas terem sido aplicadas durante o outono, podendo em outros meses existir variação de respostas. 


\section{RESULTADOS E DUSCUSSÃO}

A região possui um grande potencial atrativo ao público, visto estar localizada em uma região com vista privilegiada da cidade do Porto, com bons pontos que proporcionam o estar e o encontro de pessoas, com edifícios com grande potencial de uso.

No entanto, algumas questões observadas não permitem o destaque de algumas das potencialidades citadas (Quadro 1). A única via de acesso de veículos à área se configura como uma barreira física do espaço, impedindo o grande público utilizador dos gramados para contemplação da vista de apropriar-se totalmente da zona. Isso faz com que o passeio público adjacente aos edifícios comerciais não seja muito utilizado e concorra para a escassa existência de comércio atrativo ao público dominante.

Dessa forma, a região se estabelece com um setor muito utilizado e bem aproveitado e outro de baixo uso e aproveitamento pelos usuários. A fazer da zona um local sem uniformidade, sem uma linguagem única, apresenta-se aos usuários uma fragmentação também visual. A falta de uniformidade dos materiais usados no piso contribui para a sensação de fragmentação do espaço e dá ao local barreiras visuais de acesso.

A região dos gramados, utilizados principalmente para a contemplação da vista local, proporciona aos usuários do Passeio das Virtudes uma ótima interação social, um local de uso coletivo e partilhado. No entanto, a falta de rampas de acesso não proporciona a acessibilidade universal aos usuários com mobilidade reduzida, e não proporciona a total integração do público e a interação social entre eles.

Quadro 1: Diagnóstico, pontos positivos e negativos.

\begin{tabular}{|c|c|}
\hline PONTOS NEGATIVOS & PONTOS POSITIVOS \\
\hline Espaço com grande potencialidade de uso ativo; & Fragmentação do espaço por via de veículos; \\
\hline Existência de edifícios comerciais; & Comércio pouco atrativo; \\
\hline $\begin{array}{c}\text { Gramados que proporcionam a vista para a cidade e sua } \\
\text { paisagem natural; }\end{array}$ & Passeio público não é apropriado pelos usuários; \\
\hline $\begin{array}{c}\text { Espaço proporciona boa interação social com o público. } \\
\text { Falta de acessibilidade na área de gramados, o que } \\
\text { dificulta a interação entre os diferentes públicos. }\end{array}$ \\
\hline
\end{tabular}

Fonte: os autores.

De acordo com os itens avaliados, com respeito a qualidade do ambiente urbano do Passeio das Virtudes, os resultados obtidos constam do Quadro 2.

O ambiente do Passeio das Virtudes revela a grande importância cultural e histórica do local para a cidade do Porto, uma herança de outra configuração urbana. Isso acontece pelo grande valor simbólico desse espaço para a cidade, a vista da paisagem urbana e do importante Rio Douro. Porém, a configuração morfológica da cidade, de certa forma, deixa o local à beira da cidade medieval, no perímetro da cidade histórica. Isso acarreta o esquecimento da zona pelas entidades públicas e privadas, não tendo emergido assim um interesse econômico pelo local, o que pode ser motivado também pela falta de conexão do espaço com as questões do capital turístico da cidade. 
Quadro 2 - Resultados, pontos positivos e negativos.

\begin{tabular}{|c|c|}
\hline PONTOS NEGATIVOS & PONTOS POSITIVOS \\
\hline Bom microclima; & Falta de distribuição de fontes de água; \\
\hline Recipiente para o luxo; & Falta de textura de superfície; \\
\hline $\begin{array}{l}\text { Local pensado nas pessoas com mobilidade reduzida } \\
\text { (rampas, caminhos pedonais largos); }\end{array}$ & Bancos desconfortáveis; \\
\hline Diferentes possibilidades para sentar (relva, muro); & Fraca iluminação; \\
\hline Restauração; & $\begin{array}{l}\text { Falta de disponibilidade dos meios de segurança, sendo } \\
\text { considerada uma área pouco segura; }\end{array}$ \\
\hline Bom espaço para relaxação; & Poucos eventos; \\
\hline Movimentação variada; & Inexistência de recreio infantil; \\
\hline Espaço de contemplação; & Ocorrência de atividades ilícitas; \\
\hline Bom acesso físico; & $\begin{array}{l}\text { Abertura visual para a envolvência imediata limitada } \\
\text { (gradeamento); }\end{array}$ \\
\hline Boa liberdade de ação, bem como a fruição da área; & $\begin{array}{c}\text { Falta de sinalética estratégica a indicar o Passeio das } \\
\text { Virtudes; }\end{array}$ \\
\hline Presença de pinturas murais no qual dão vida à área; & A rede pedonal necessita de uma nova estrutura; \\
\hline Desenho linear, dando uma boa legibilidade à área; & $\begin{array}{l}\text { Falta de definição de usos para os serviços de limpeza, } \\
\text { irrigação e restante manutenção da área; }\end{array}$ \\
\hline Área de grande relevância para a cidade; & $\begin{array}{l}\text { Disponibilidade dos meios humanos necessários são } \\
\text { escassos; }\end{array}$ \\
\hline A área permite ligações individuais e em grupo; & $\begin{array}{l}\text { O declive e a falta de grelhas não são adequado à } \\
\text { irrigação e à drenagem das águas da chuva. }\end{array}$ \\
\hline \multicolumn{2}{|l|}{$\begin{array}{c}\text { A área permite ligação biológicas e psicológicas aos } \\
\text { utilizadores; }\end{array}$} \\
\hline \multicolumn{2}{|l|}{ Materiais do piso facilmente substituíveis; } \\
\hline Espécies de acordo com o clima e a natureza do solo. & \\
\hline
\end{tabular}

Fonte: os autores.

De acordo com a análise feita através do survey e das observações dos próprios pesquisadores, foi possível perceber a existência da apropriação parcial do espaço pelas pessoas, com apego pela simbologia histórico cultural do local. Isso faz com que o espaço tenha um grande potencial de atração e de atividades para a cidade, podendo ser mais bem utilizado e mais apropriado pelos moradores locais, turistas, eventos e demais usos socioculturais.

No entanto, atualmente, revela-se apenas a bela vista para a paisagem como o único atrativo de importância para o local, não havendo outros atributos que atraiam os usuários ou que situem o espaço na contemporaneidade, como edifícios atrativos, usos dinâmicos e atuais e eventos culturais de interesse. Em consequência o local não é usado em todos os momentos do dia e a noite se torna um local abandonado que não proporciona sensação de segurança para quem necessita passar pela região.

Dessa forma, com estratégias de intervenção no espaço as potencialidades existentes podem ser exaltadas, de forma a aflorar novos usos e atrativos ao local, e assim, promover o enriquecimento cultural contemporâneo e a história local. 


\section{CONSIDERAÇÕES FINAIS}

Constata-se a importância de entender as dinâmicas dos espaços públicos intraurbanos nas cidades e sua importância na vivência do ambiente urbano a partir deles. Além disso, a cultura é dinâmica e provoca interpretações e reinterpretações dos espaços e conceitos acerca deles. Somado a isso, as intervenções na cidade do Porto reconfiguraram os aspectos físicos e simbólicos da cidade, sendo, portanto, fundamental compreender as novas visões e teorias sobre os espaços públicos e as tendências de intervenções em vista das suas requalificações.

Somado a isso, com o estudo realizado foi possível perceber a importância da análise do espaço público a partir de um misto de metodologias, as quais permitem coletar informações e entender o espaço a partir de diferentes perspectivas. Além da clareza na leitura dos dados coletados, é uma metodologia relevante para orientar uma intervenção lúcida e coerente com o espaço, de forma a intervir com a intensidade correta, minimamente impactante à configuração urbana existente.

Percebeu-se que para espaços simbólicos de grande importância para a cidade, mesmos esquecidos pelas intervenções, planos ou programas governamentais, ainda são apropriados pelos usuários. Apesar de existirem influências físicas ou funcionais negativas, as quais mitigam as potencialidades do espaço, ainda pode haver uso mais intenso do local.

A partir disso, e do conhecimento integral da região e das necessidades do público usuário do espaço, foi possível evidenciar os pontos positivos do ambiente do Passeio das Virtudes. Ao buscar informações e diagnósticos que proporcionem à cidade um ambiente urbano ainda mais vivo, de atração ao público, que garante bem-estar, segurança, conforto e acessibilidade aos usuários, vai-se assim ao encontro das políticas de dinamização e transformação do lugar num polo de cultura e lazer, não só voltado para o turismo, como para uma ampla gama de usuários locais.

\section{REFERÊNCIAS}

ALVES, Fernando Brandão. Avaliação da qualidade do espaço público urbano: proposta metodológica. Porto: Calouste Gulbenkian, 2003.

ALVES, Marta Raquel da Silva et al. Apropriação pelos usuários de Espaços Públicos em bairros da zona sul da cidade de Teresina, PI. In: ENCONTRO NACIONAL DE ENSINO DE PAISAGISMO EM ESCOLAS DE ARQUITETURA E URBANISMO NO BRASIL 7, 2004, Belo Horizonte. Anais... Belo Horizonte: UFMG, 2004.

AMP. Caracterização da AMP. 2011. Disponível em: http:/ / portal.amp.pt/es/4/municipios/porto/stats/ demografia/\#FOCO_4. Acesso em: 26 fev. 2019.

ÁRVORE - Cooperativa de Actividades Artísticas. Quem somos. Disponível em: http:/ / www.arvorecoop. pt/sobre. Acesso em: 20 fev. 2019.

ÁRVORE - Escola Artística e Profissional. Apresentação. Disponível em: https://www.arvore.pt/index. php. Acesso em: 13 dez. 2018.

BARREIRA, Hugo; ROSAS, Lúcia; BOTELHO, Maria Leonor. Jardim e Passeio das Virtudes: uma paisagem histórica urbana. In: BARREIRA, Hugo; ROSAS, Lúcia; BOTELHO, Maria Leonor. Passeio e Jardim das 
Virtudes Porto: CITCEM, 2017. p. 5-12. Disponível em: https://sigarra.up.pt/flup/pt/pub_geral.pub_ view?pi_pub_base_id=207522. Acesso em: 20 fev. 2019.

CASTRO, Alexandra. Espaços Públicos, Coexistência Social e Civilidade: contributos para uma reflexão sobre os Espaços Públicos Urbanos. Revista cidades, comunidades e territórios, n.5, p. 53-67, 2002.

CASTRO, Luiz Guilherme Rivera de. O que é espaço público? AU - Arquitetura e Urbanismo, São Paulo, v. 28, n. 232, jul. 2013. Mensal. Disponível em: http:/ / www.au.pini.com.br/arquitetura-urbanismo/232/oque-e-espaco-publico-292045-1.aspx. Acesso em: 20 fev. 2019.

FORTUNA, Carlos. Culturas urbanas e espaços públicos: sobre as cidades e a emergência de um novo paradigma sociológico. Revista Crítica de Ciências Sociais, Coimbra, n. 63, p.123-148, 2002. Disponível em: http:/ /rccs.revues.org/1272. Acesso em: 20 fev. 2019.

GEHL, Jan. Cidades para as pessoas. São Paulo: Perspectiva, 2015.

GEHL, Jan. La humanización del espacio urbano: la vida social entre los edificios. Barcelona: Reverte, 2008.

GEHL, Jan; GEMZØE, Lars. Novos espaços urbanos. Barcelona: Editorial Gustavo Gili, 2000.

GERHARDT, Tatiana E.; SILVEIRA, Denise T. Metodologia de pesquisa. Porto Alegre: Ed. UFRGS, 2009. Disponível em: http:/ / www.ufrgs.br/cursopgdr/downloadsSerie/derad005.pdf. Acesso em: 20 fev. 2019.

GONÇALVES, Jorge Manuel. Os espaços públicos na reconfiguração física e social da cidade. Lisboa, 2004. Tese (Doutorado em Geografia) - Universidade Nova de Lisboa, Portugal. Disponível em: https:// www.researchgate.net/publication/266795292. Acesso em: 20 fev. 2019.

JACOBS, Jane. A morte e a vida das grandes cidades. São Paulo: Martins Fontes, 2000.

KARSSENBERG,Hans; LAVEN,Jeroen. A cidadeaonível dos olhos: estratégia do plinth. In: KARSSENBERG, Hans. A cidade ao nível dos olhos: uma lição para os plinths. 2.ed. Porto Alegre: Ed PUC-RS, 2015. p. 14-25.

MADDEN, Kathleen. (Org.). How to Turn a Place Around: A handbook for creating Successful Public Spaces. New York: Project Fo Public Spaces, 2001.

MATOS, Fátima Loureiro de. Espaços públicos e qualidade de vida nas cidades: o caso da cidade Porto. Observatorium, Porto, v. 2, n. 4, p.17-33, jul. 2010. Disponível em: http:/ /www.observatorium.ig.ufu.br/ pdfs/2edicao/n4/Espacos_publicos.pdf. Acesso em: 20 fev. 2019.

MEDINA, Xavier; ÁVAREZ, Marcelo. El lugar por donde pasa la vida... Los mercados y las demandas urbanas contemporáneas: Barcelona y Buenos Aires. In: MEDINA, Xavier; AVILA, Ricardo; GARINE, Igor de. Food, Imagineries and Cultural Frontiers. Guadalajara: Universidad de Guadalajara, 2009. p. 183-201. (Estudios del hombre, 24).

QUARESMA, Cláudia et al. O passeio das Virtudes e a rutura do Palácio da Justiça. In: BARREIRA, Hugo; ROSAS, Lúcia; BOTELHO, Maria Leonor. Jardim e Passeio das Virtudes: uma paisagem histórica urbana. Porto: CITCEM, 2017. p. 44-54.

ROLNIK, Raquel. O que é cidade. São Paulo: Brasiliense, 1998.

RUMBLE, Heather; ANGEOLETTO, Fabio; CONNOP, Stuart et al. Understanding and applying ecological principles in cities. In: OLIVEIRA, F.L.; MELL, I. (Eds.). Planning Cities with Nature: Theories, Strategies and Methods. Amsterdam: Springer Nature, 2019. p. 217-234.

SANTOS, Filipa Catarina Antunes dos. Características físicas e sociais do espaço público: nove casos de estudo sobre as vivências urbanas no centro histórico de Lisboa. Lisboa, 2008. Dissertação (Mestrado em Arquitectura) - Universidade Técnica de Lisboa, Portugal. Disponível em: https://fenix.tecnico.ulisboa. pt/downloadFile/395137854861/Disserta\%C3\%A7\%C3\%A3o.pdf. Acesso em: 20 fev. 2019.

ZAMANI, Zahra; LEE, JONG S.; PIPPI, Luis Guilherme Aita et al. Exploring behaviors and perceptions of users in a neighborhood park. Saarbrücken: Lap Lambert Academic Pub., 2014.

Data de submissão: 27/fev./2019

Data de aceite: 12/ago./2019 